\title{
透視図と絵画における省略遠近法
}

\author{
井野 智（北海道情報大学） \\ 辻 美奈子（株式会社 INAX） \\ 佐藤仁一朗（東北工業大学） \\ 宮腰 直幸（北海道大学大学院工学研究科都市環境工学専攻）
}

要旨：CADを用いて作成した建築パースの多くは、外壁の夕イル目地、サッシ、ガラス空などの表現が全面均一に 仕上げられているため遠近感やスケール感にそしく、点景や遠景の描き込みが不十分なため見る人に無機顊な感じをあ たえる。CAD作品のもつこのような欠点を改善するには、視点からの距離に応じて描き込みを簡略化する、所謂、省 略遠近法の導入が不可欠である。本研究では、建築を描く際に画家やパース専門家が省略遠近法や点景などをどのよう に描画しているかを作品分析で明らかにするとともに、細密すきる描画が遠近感を損ないやすい鉛直材の透視図上の幅 を計算で求め、複線表現や着色限界の指標值を検討する資料を得ることを目的としている。

前半の作品分析では、(1)CADによる作品、(2)建築パース尃門家による手描き作品、(3)画家または建築家による絵画 各4例を相互に比較し、(2か建物自体の形態・色彩・テクスチャーや周边環境をもっとも的確に表現していることを明 らかにしたのち、複数のパース作品集より、(1)事務所建築 (2)商業建築、(3)公共建築 (4)レジャ一施設、(5)集合住宅各 20 例を抜粋し、建築細部の簡略表現や点景・遠景描画などの技法について定量的な分析を試みた。一方、鉛直材の簡 略表現に関する定量的検討については、円形または正方形断面をもつ直材の透視図上の幅と、隣接材との隙間を求める 計算式を導き、上記指標值を具体的に検討できる資料を提示した。

キーワード：CAD／CAM、透視図、省略遠近法

1.はじめに

近年 建築の設計製図はCADを用いて行われるの が通例であり、透視図も例外ではない。CADを使っ た建物の透視図は、省略遠近法法が不完全なため不自 然な感じを与える場合が少なくない。省略遠近法にお ける省略の度合いは、作者の経験的な判断によるとこ ろが大きく、このことを明確にした研究はほとんど見 られないようである。

本論では、省略遠近法を取り上げ、実作品の分析と 幾何学的考察をもとに、透視図から受ける印象をより 実際に近いものとするための簡略化手法の幾つかを提 示することを目的としている。

2. C AD作品と手描き作品の比較

省略の程度に大きな違いのある、(1)C ADを使った
建物の透視図〔注 1】、(2パース専門家が描いた建物の 透視図〔注 2〕、(3)建築家または画家が描いた建物の絵 〔注 3〕各4例を相互に比較し、実空間に近いイメー ジを形成する上で省略遠近法の果たす役割などについ て、以下のことを明らかにした。

（1）省略のない透視図は遠近感とスケール感に欠け、模 型のように見える。

（2）後景や前景を単一色または無色にすると、模型のよ うに見える。

（3）外壁や空ガラスを均一に着色した透視図は不自然 で無機質に見える。

(4)（1)〜(3)はC AD作品に多い。パース専門家の作品 にこのような単純表現はあまりなく建物と周辺環境の イメージ形成に効果的な簡略表現か㳩に使われている。

=069-8585 江別市西野幌 59-2 
（5）画家の作品は、建物細部の描きこみは少ないか、建 物の輪郭や色彩的雲囲気を的確にとらえた例が多い。

\section{3. 手描き作品の分析}

C AD作品および絵画と比較し、建築パースの専門 家が描いた透視図（以下「建築パース」という）は、 建物の形態を正確に表わし、省略遠近法をより的確に 具現していることを前節で明らかにした。ここでは、 建築パース作品集〔文献 1〜5] から、表 1 に掲げる 事務所建築、商業建築、レジャー施設、公共建築、集 合住宅各 20 例、合計 100 例を抜粋し、表 2 に列挙し た項目を描画するに当たって、どのような省略がなさ れているかを分析した。

表 3は調査項目一つ一つについて、用途別内訳が判 るよう分析結果を集計したものである。図 1 は、用途 別の違いが一目できるよう、空ガラス越しの室内描画 の有無 目地の描き込み状況、隣接建物の描画簡略の 程度、点景として描き込んだ人数と台数、背景である 天空の描き方を比較したものである。

作品分析の主な結果を以下に要約する。

（1）壁面の彩色にムラがあり、これを境にして省略表現 する例が多い。

(2) タイル目地なと描き込みは視点近くを克明に表わ

し、遠方を省略している例が多い。

（3）ガラス面に映る周辺の光累を描く例が多い。

（4）空越しの室内状況を描写した例は多いが、描きこみ が全面に及ぶ例はあまりない。

（5）(1)〜(4)については、建物正面よりも側面で省略の 度合いが大きい。

（6）隣接建物は、輪郭、階数などがようやく判る程度に 簡略表現されている。

（7）多数の人物と自動車が点景として描かれている。そ れぞれ 1 作品当たり平均 23.0 人、 5.7 台であった。

(8) 点詈としての樹木は $85 \%$ 以上、花壇や植え込みは $50 \%$ 以上描かれていた。

（9）道路または広場を前景に描いた作品は全体の約 85\%であった。

(10)路面に写る樹木や建物の虚像を入れた作品が約 25\%、いずれも省力表現ではあるが街路に清潔感を与 えている。

(11)前景描写では、対象建物近傍の描きこみを密にし、 視点寄りをボカシて表現する例が多い。
（12)後景としての天空は、着色した例か䄪 $30 \%$ 、用紙 の生地そのものまたはこれに雲を描き入れた例が約 40\%あった。

表 1 専門家が描いた建築パース作品出典一覧

\begin{tabular}{|c|c|c|c|c|c|}
\hline & $\begin{array}{l}\text { 事務所 } \\
\text { 筑 }\end{array}$ & $\begin{array}{l}\text { 商 } \\
\text { 業 } \\
\text { 築 } \\
\end{array}$ & $\begin{array}{l}\text { 公 } \\
\text { 共 } \\
\text { 築 }\end{array}$ & $\begin{array}{l}\text { 集 合 } \\
\text { 住 宅 }\end{array}$ & 施 設 \\
\hline & A 003 & A 033 & A 153 & & A 073 \\
\hline & 4008 & A 039 & B 047 & & A 085 \\
\hline & A 016 & $\begin{array}{l}\mathrm{A} \quad 041 \\
\end{array}$ & $\bar{B}$ & A & A 173 \\
\hline 4 & A 026 & A 042 & 050 & A 140 & A 175 \\
\hline 5 & A 030 & A 043 & 054 & 133 & A 176 \\
\hline 6 & B 008 & A 052 & 059 & & A 186 \\
\hline 7 & B 013 & A 053 & 059 & & B 085 \\
\hline 8 & B 013 & A 054 & 060 & 39 & B 096 \\
\hline 9 & B 015 & A 055 & B $\quad 060$ & 142 & B 097 \\
\hline 0 & B 020 & A 059 & B 069 & B 142 & B 098 \\
\hline & B 027 & A 061 & B 071 & B 144 & B 102 \\
\hline 12 & В 028 & A 063 & B 071 & B 144 & B 102 \\
\hline 13 & B 028 & A 193 & B 076 & B 145 & 107 \\
\hline 14 & В 032 & B 009 & 111 & 146 & B 108 \\
\hline 15 & B 035 & B 016 & C 120 & 148 & B 110 \\
\hline 16 & $\mathrm{~B} 0$ & C 007 & D $\quad 028$ & 149 & $\mathrm{~B}$ \\
\hline 7 & $\mathrm{C} 0$ & C 043 & D 139 & B 161 & \\
\hline 8 & D 023 & C 067 & D 142 & C 112 & C 108 \\
\hline 9 & D 054 & C 072 & D 142 & C 112 & D 133 \\
\hline & 055 & & D 149 & E 003 & D 133 \\
\hline 凡 & \multicolumn{5}{|c|}{ 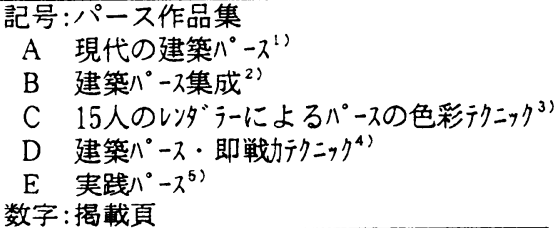 } \\
\hline
\end{tabular}

\section{表 2 建築パース作品の分析項目一覧}

\begin{tabular}{|c|c|c|}
\hline \multirow{4}{*}{ 項 } & 掲載図書 & 書籍名、掲载頁 \\
\hline & 作品名等 & 建物名称、用途 \\
\hline & 作者 & 企業名、個人名 \\
\hline & 透視図法 & 有角透視、平行透視 \\
\hline \multirow{10}{*}{ 対象建物 } & \multirow{5}{*}{ 外壁正面 } & 外壁の着色 /ムラの有無 \\
\hline & & 目地 /全面、一部、なし \\
\hline & & ガラス面／反射光景の有無 \\
\hline & & 室内／照明等の有無 \\
\hline & & 㓌影／正確さ \\
\hline & \multirow{5}{*}{ 外壁側面 } & 外壁の着色 /ムラの有無 \\
\hline & & 目地 /全面、一部、なし \\
\hline & & ガラス面／反射光景の有無 \\
\hline & & 室内／照明等の有無 \\
\hline & & 㓌影／正確さ \\
\hline \multirow{5}{*}{ 隣接建物 } & \multirow{5}{*}{ 描き込み } & 着色／塗り分け、単色による灌淡 \\
\hline & & 階数、スパン／判別の可否 \\
\hline & & 目地／全面、一部、なし \\
\hline & & サッシ＼cjkstart全面、一部、なし \\
\hline & & 㓌影／有無 \\
\hline \multirow{7}{*}{ 点 } & \multirow{2}{*}{ 人物 } & 人数 \\
\hline & & 着色，塗り分け、単色 \\
\hline & \multirow{2}{*}{ 自動車 } & 台数 乗用車、その他 \\
\hline & & 着色、塗り分け、単色 \\
\hline & \multirow{2}{*}{ 樹木 } & 幹枝，有無 \\
\hline & & 林，有無 \\
\hline & 植え込み & 場所，有無 \\
\hline \multirow{4}{*}{ 全景後景 } & \multirow{2}{*}{ 全景 } & 種類，道路、芝、庭、水辺、広場 \\
\hline & & 道路の反射，有無 \\
\hline & \multirow{2}{*}{ 後景 } & 森林，有無 \\
\hline & & 山有無 \\
\hline \multirow{5}{*}{ 天 } & \multirow{2}{*}{ 天空 } & 色，単色、雲の有無 \\
\hline & & 天空率 \\
\hline & \multirow{3}{*}{ 地面 } & 色，塗り分け、単色 \\
\hline & & 地面率 \\
\hline & & 視点近くの簡略表現 \\
\hline
\end{tabular}


表 3 専門家が描いた建築パース作品分析結果

\begin{tabular}{|c|c|c|c|c|c|c|c|c|c|}
\hline & 用 & 途 & & 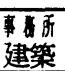 & $\begin{array}{l}\text { 商業 } \\
\text { 建築 }\end{array}$ & $\begin{array}{l}\text { 枀共 } \\
\text { 建淛 }\end{array}$ & $\begin{array}{l}\text { 集合 } \\
\text { 住宅 }\end{array}$ & 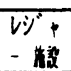 & 合計 \\
\hline 図 & 有自 & 再透視 & & 16 & 17 & 15 & 18 & 15 & 81 \\
\hline 菭 & 平行 & 丁透視 & & 4 & 3 & 5 & 2 & 5 & 19 \\
\hline \multirow{26}{*}{ 建 } & \multirow{13}{*}{$\begin{array}{l}\text { 外 } \\
\text { 壁 } \\
\text { 正 } \\
\text { 面 }\end{array}$} & 壁面の & あり & 15 & 16 & 14 & 15 & 10 & 70 \\
\hline & & 厶ラ & なし & 5 & 4 & 6 & 5 & 10 & 30 \\
\hline & & & 全面あり & 11 & 5 & 8 & 8 & 4 & 36 \\
\hline & & 目地 & 一部あり & 9 & 10 & 10 & 9 & 6 & 44 \\
\hline & & & なし & 0 & 5 & 2 & 3 & 10 & 20 \\
\hline & & ガラ人面 & あら & 16 & 9 & 14 & 14 & 9 & 62 \\
\hline & & の反射 & なし & 4 & 11 & 6 & 6 & 11 & 38 \\
\hline & & 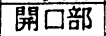 & 全面あり & 2 & 7 & 4 & 3 & 5 & 21 \\
\hline & & に室内 & 一部あり & 16 & 13 & 9 & 16 & 13 & 67 \\
\hline & & の描写 & なし & 2 & 0 & 7 & 1 & 2 & 12 \\
\hline & & & ほほ正確 & 19 & 18 & 20 & 19 & 19 & 95 \\
\hline & & 陰影 & 不正確 & 0 & 2 & 0 & 1 & 0 & 3 \\
\hline & & & なし & 1 & 0 & 0 & 0 & 1 & 2 \\
\hline & \multirow{13}{*}{$\begin{array}{l}\text { 外 } \\
\text { 壁 } \\
\text { 側 } \\
\text { 面 }\end{array}$} & 壁面の & あり & 13 & 11 & 11 & 12 & 8 & 55 \\
\hline & & ムラ & なし & 5 & 6 & 7 & 6 & 6 & 30 \\
\hline & & & 全面おり & 4 & 6 & 2 & 7 & & 21 \\
\hline & & 目地 & 部あり & 14 & 9 & 13 & 6 & 4 & 46 \\
\hline & & & なし & 0 & 2 & 3 & 5 & 8 & 18 \\
\hline & & ガラス面 & あり & 7 & 3 & 8 & 9 & 4 & 31 \\
\hline & & の反射 & なし & 7 & 11 & 7 & 8 & 7 & 40 \\
\hline & & 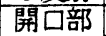 & 全面あり & 3 & 4 & 2 & 1 & 1 & 11 \\
\hline & & に室内 & 部あり & 5 & 5 & 5 & 11 & 3 & 29 \\
\hline & & の描写 & なし & 6 & 5 & 8 & 4 & 7 & 30 \\
\hline & & & 正確 & 14 & 15 & 18 & 17 & 12 & 76 \\
\hline & & 㓌影 & 不正確 & 3 & 2 & 0 & 1 & 0 & 6 \\
\hline & & & なし & 1 & 0 & 0 & 0 & & 2 \\
\hline \multirow{12}{*}{$\begin{array}{l}\text { 隣 } \\
\text { 接 } \\
\text { 建 } \\
\text { 物 }\end{array}$} & \multirow{12}{*}{$\begin{array}{l}\text { 描 } \\
\text { き } \\
\text { 込 } \\
\text { み }\end{array}$} & & 多色 & 10 & 9 & 6 & 7 & & 33 \\
\hline & & 看色 & 単色漕淡 & 8 & 8 & 0 & 3 & 0 & 19 \\
\hline & & 階数 - & 判別可 & 14 & 11 & 5 & 8 & 1 & 39 \\
\hline & & スパン & 不明 & 4 & 6 & 1 & 2 & 0 & 13 \\
\hline & & & 全面あり & 3 & 4 & 0 & 0 & 0 & 7 \\
\hline & & 目地 & 部あり & 5 & 2 & 2 & 3 & 0 & 12 \\
\hline & & & 小L & 10 & 11 & 4 & 7 & 1 & 33 \\
\hline & & & 全面あり & 3 & 5 & 2 & 0 & 0 & 10 \\
\hline & & サッシ & 部あり & 1 & 4 & 0 & 2 & 1 & 8 \\
\hline & & & なL & 13 & 8 & 4 & 8 & 0 & 33 \\
\hline & & & あり & 11 & 10 & 5 & 4 & & 31 \\
\hline & & 陰影 & なL & 7 & 7 & & 6 & 0 & 21 \\
\hline & & & あり & 20 & 20 & 20 & 19 & 20 & 99 \\
\hline & & & なし & 0 & 0 & 0 & 1 & 0 & \\
\hline & 人 & & 平均人数 & 24.2 & 39.6 & 22.5 & 12.9 & 15.9 & 23.0 \\
\hline & 物 & & 多色 & 14 & 8 & 13 & 17 & 16 & 68 \\
\hline & & 着色 & 多色+単 & 6 & 12 & 7 & 2 & 3 & 30 \\
\hline & & & 単色 & 0 & 0 & 0 & 1 & 1 & 2 \\
\hline & & & あり & 20 & 20 & 19 & 19 & 13 & 91 \\
\hline 点 & 自 & & なし & 0 & 0 & & 1 & 7 & 9 \\
\hline & 動 & & 平均台数 & 5.8 & 8.9 & 5.6 & 5.6 & 2.2 & 5.6 \\
\hline 景 & 車 & 差角 & 多色 & 19 & 20 & 19 & 19 & 13 & 90 \\
\hline & & 省巴 & 単色 & 1 & 0 & 0 & 0 & 0 & \\
\hline & & & あり & 15 & 16 & 16 & 17 & 20 & 84 \\
\hline & & 幹依 & なし & 5 & 4 & 4 & 3 & 0 & 16 \\
\hline & 相 & & あり & 2 & 3 & 12 & 9 & 13 & 39 \\
\hline & & 不 & なし & 18 & 17 & 8 & 11 & 7 & 61 \\
\hline & 个个 & & あり & 11 & 5 & 19 & 14 & 6 & 55 \\
\hline & & 㮩阮 & なし & 9 & 15 & & 6 & 14 & 45 \\
\hline & & & 道路 & 19 & 19 & 13 & 14 & 4 & 69 \\
\hline & & & 広場 & 1 & 0 & 4 & 2 & 10 & 17 \\
\hline & 前 & 種類 & 駐車場 & 0 & 1 & $I$ & 3 & 0 & 5 \\
\hline & & & 芝 & 0 & 0 & 0 & 1 & 4 & 5 \\
\hline 盟 & 景 & & 水辺 & 0 & 0 & & 0 & 2 & 3 \\
\hline 京 & & 反的 & あり & 8 & 7 & 6 & 4 & 0 & 25 \\
\hline 營 & & D邪 & なし & 12 & 13 & 14 & 16 & 20 & 75 \\
\hline & & & あり & 0 & 0 & 6 & 5 & 5 & 16 \\
\hline & 中 & 林林 & なし & 20 & 20 & 14 & 15 & 15 & 84 \\
\hline & 皇 & ل & あり & & 0 & 9 & 0 & 12 & 22 \\
\hline & & Ш & なL & 19 & 20 & 11 & 20 & 8 & 78 \\
\hline & & & 平均率 & 0.2 & 0.2 & 0.4 & 0.2 & 0.4 & 0.3 \\
\hline & & & 多色 & 5 & 3 & 7 & 9 & 13 & 37 \\
\hline & 空 & & 単色 & 5 & 5 & 9 & 3 & 0 & 22 \\
\hline 天 & & 龺巴 & 雲のみ & 1 & & & 4 & 3 & 10 \\
\hline & & & 無地 & 9 & 11 & & 4 & 3 & 10 \\
\hline 地 & & & 平均率 & 0.1 & 0.1 & 0.3 & 0.2 & 0.3 & 0.2 \\
\hline & 地 & & 多色 & 14 & 13 & 16 & 16 & 19 & 78 \\
\hline & 面 & 着色 & 单色 & 6 & 6 & 3 & 4 & 0 & 19 \\
\hline & & & 無地 & 0 & & & 0 & & \\
\hline
\end{tabular}

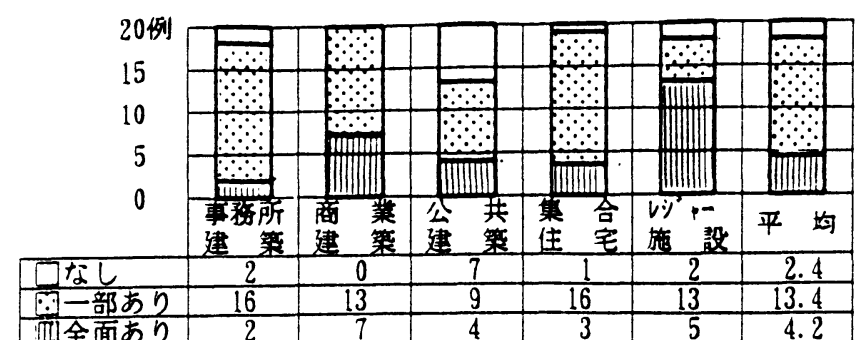

（1）正面空ガラス越しの室内描写

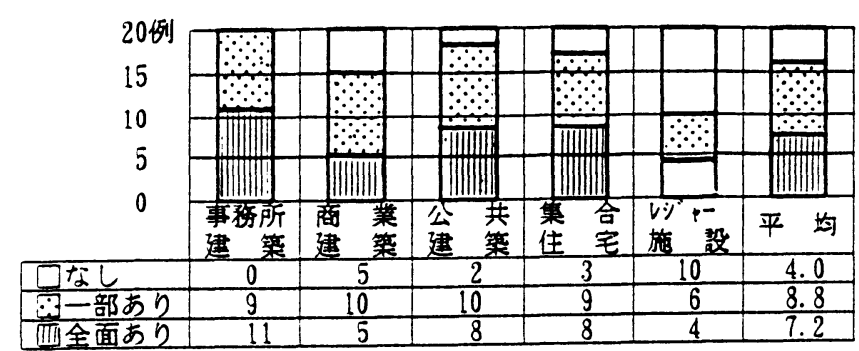

（2）正面外壁の目地の描き込み

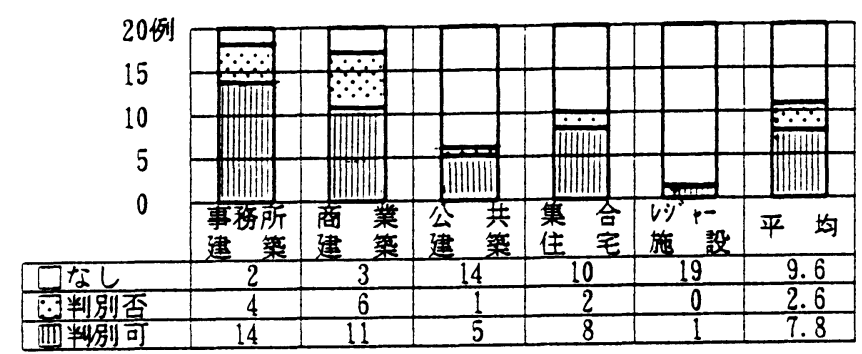

（3）接建物の階数・スパン数判別の可否

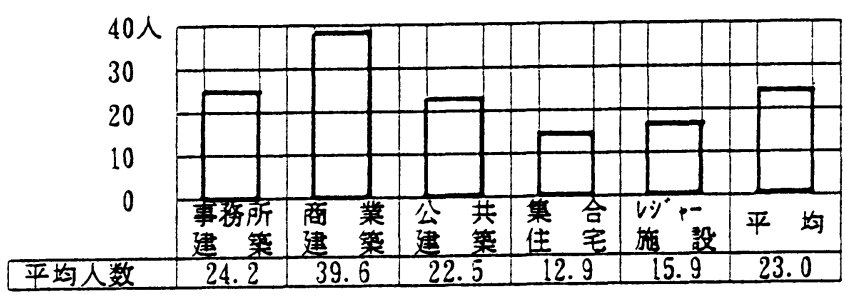

（4）点景として猫き込んだ人数

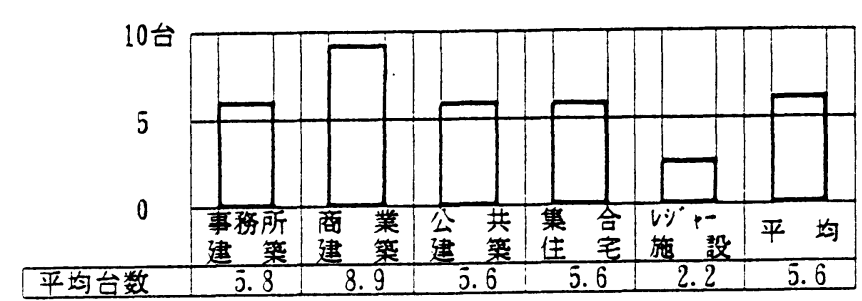

（5）点景しして描き込んだ車台数

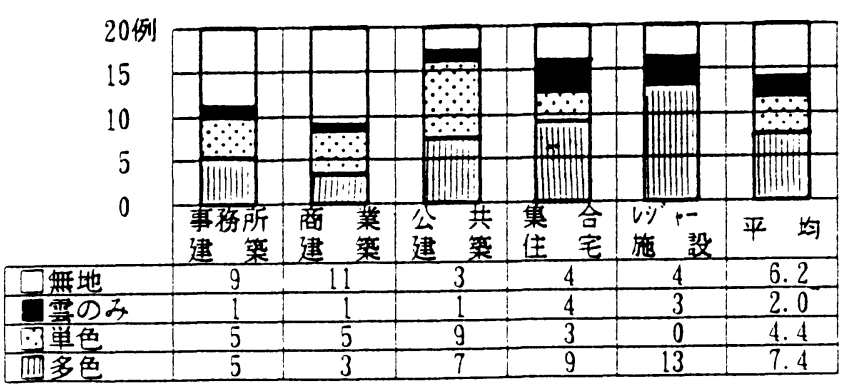

（6）天架の描き方

図1専門家が描いた建築パース作品分析結果の比较例 


\section{4. 鉛直材の幅と間隔}

柱やサッシなどの鉛直材を表わすのに，近くのもの の明面と陰面を塗り分けたり 3 本線で表わしたりする か、鉛直材が視点から遠ざかるにつれて、これらを単 色にしたり、線を 2 本または1 本に隇らすといった使 い分けをするのも省略遠近法である。ここでは、透視 図上、鉛直材の幅や粼接材との隙間が作図条件によっ てどのように変わるかを定量的に調へ 上述の省略表 現の変り目となる指標值がどのあたりにあるかを模索 した。

\section{1 円形断面の場合}

作図条件が図 2 で表わされる円形断面の透視図上の 幅 $\mathrm{x}$ と隣接材との隙間 $\Delta \mathrm{x}$ は、それそれ (1)、(2) 式となる。

$$
x=\frac{2 d r \sqrt{l^{2}+d^{2}-r^{2}+2 d l \sin \theta}}{d^{2}+2 d l \sin \theta+l^{2} \sin ^{2} \theta-r^{2}}
$$

図2 は、画面との傾き $\theta=30^{\circ}$ の建物正面の 1 階に ある直径 $1 \mathrm{~m}$ 、高さ $6 \mathrm{~m}$ 、間隔 $3 \mathrm{~m}$ の円形断面の列柱 を描いたもので、視距離 $20 \mathrm{~m}$ 、視高 $1.5 \mathrm{~m}$ 、右端円柱 の中心から $3 \mathrm{~m}$ 右寄りに視心をおく透視図である。

同じ作図条件下で、日のみを次第に小さくしていく と、右端と左端の円柱の綐横比に大きな違いが生じ、 同じ形状寸法の柱とは見えなくなってくる。平行透視 図やӨの小さな有角透視図では、縦方向と横方向の変 化が視点から部材までの距離と対応していないため、 視心から横方向へのずれが大きくなるにつれて、部材 の歪も大きくなることは周知のとおりである。原形態 を適切に表わす透視図の作戝条件として島田、浌川ら

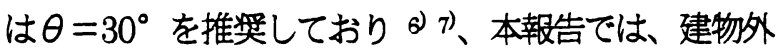
壁の直立傾角を正面用 $30^{\circ}$ 、側面用 $60^{\circ}$ に限定した。

図 3に円形断面鉛直材の逶視図上の幅、図 4に直径 $1 \mathrm{~m}$ の円柱の間隔か 6 mのときの間隔を図示した。

$$
\Delta x=d\left\{\frac{l_{2} \cos \theta \sqrt{l_{2}^{2}+2 d l_{2} \sin \theta+d^{2}-r^{2}}-r\left(d+l_{2} \sin \theta\right)}{\left(d+l_{2} \sin \theta\right) \sqrt{l_{2}^{2}+2 d l_{2} \sin \theta+d^{2}-r^{2}}+l_{2} r \cos \theta}-\frac{l_{1} \cos \theta \sqrt{l_{1}^{2}+2 d l_{1} \sin \theta+d^{2}-r^{2}}+r\left(d+l_{1} \sin \theta\right)}{\left(d+l_{1} \sin \theta\right) \sqrt{l_{1}^{2}+2 d l_{1} \sin \theta+d^{2}-r^{2}}-l_{1} r \cos \theta}\right\}
$$

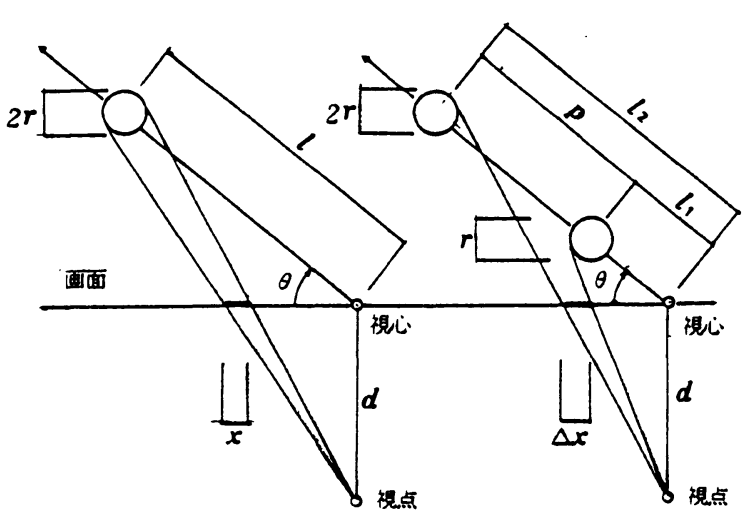

(1) 此直材の幅

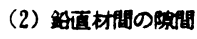

図2 円形断面鈶直材の透視図を描く作図条件

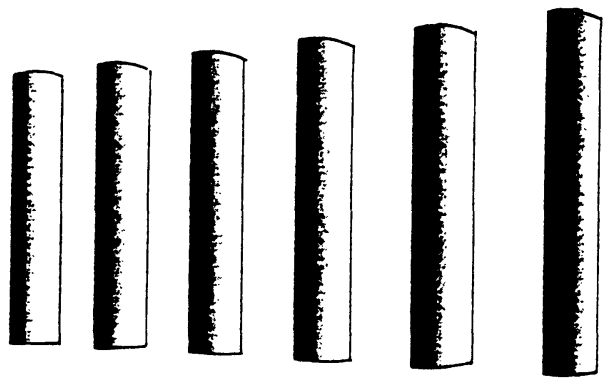

図 3 円形断面列柱の透視図 $\left(\theta=30^{\circ}\right)$
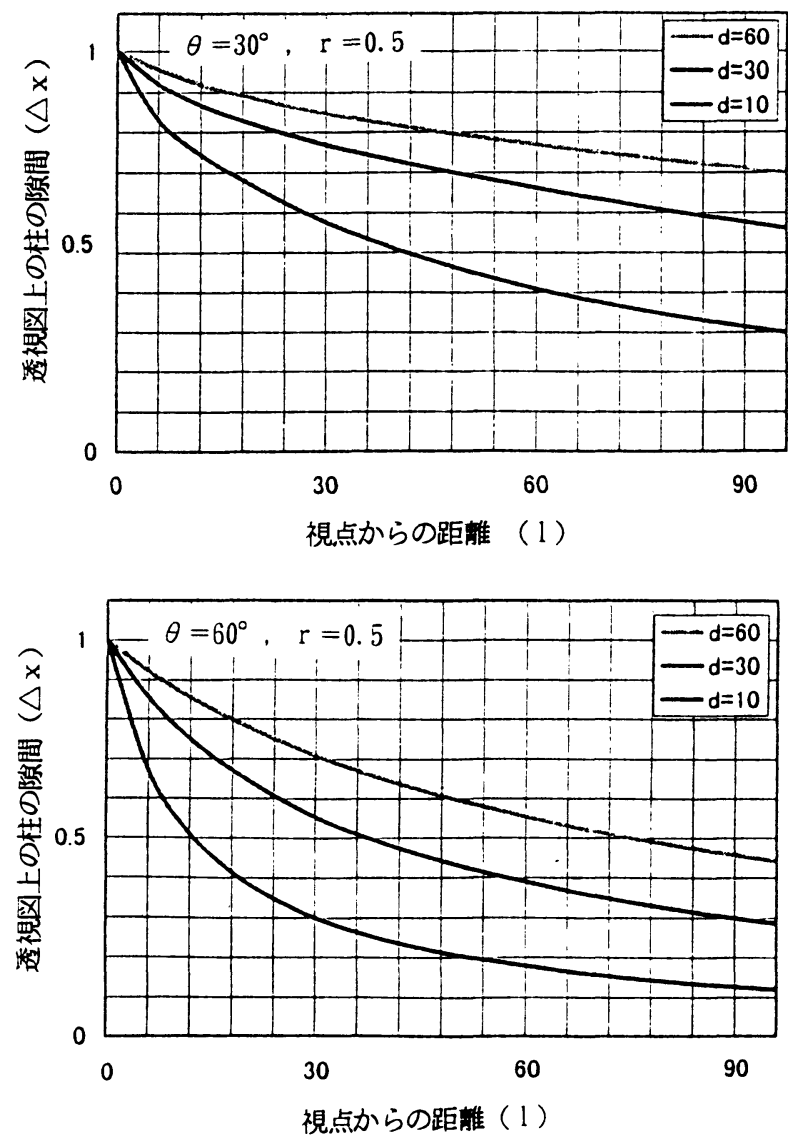

図 4 透視図上の円形断面鈶直材の幅 $\left(\theta=30^{\circ}, 60^{\circ}\right)$ 

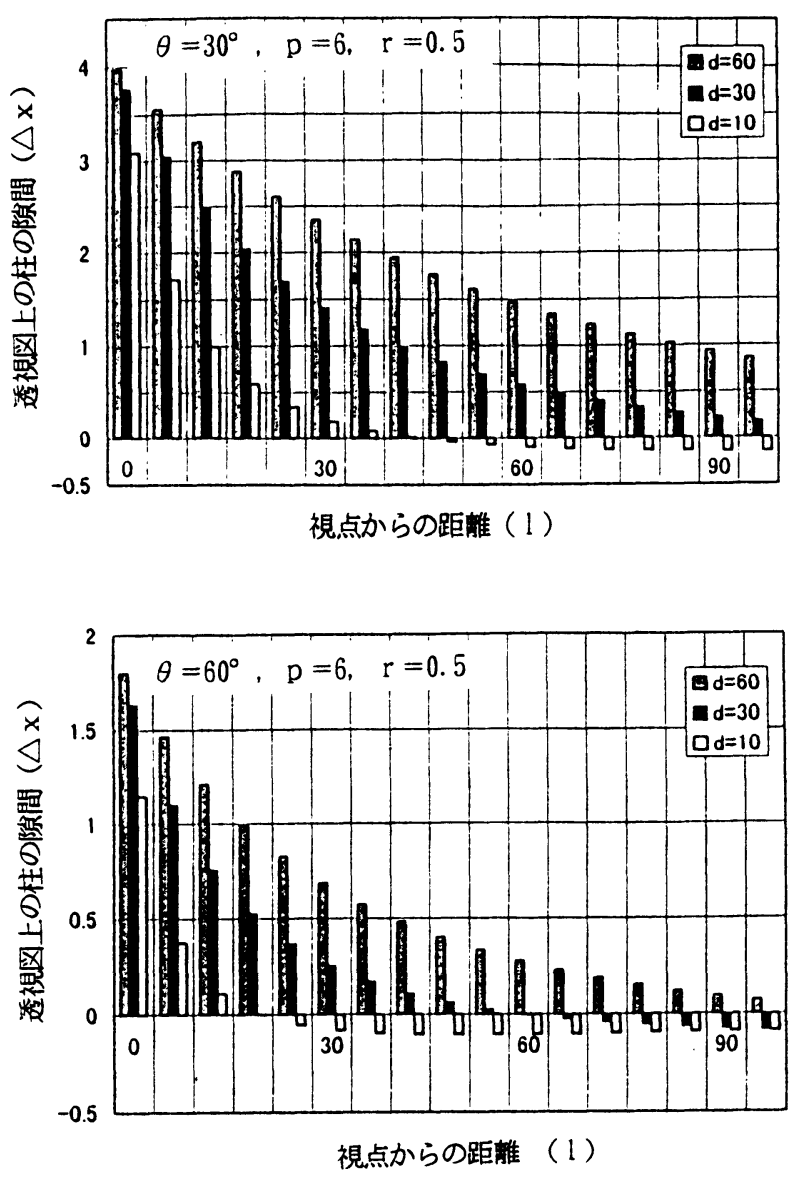

図 5 秀視図上の円形断面鉛直材間の隙間 $\left(\theta=30^{\circ}, 60^{\circ}\right)$

\section{2 正方形断面の場合}

作図条件が図 6で表わされる正方形断面の透視図上 の幅 $\mathrm{x}_{\mathrm{a}-\mathrm{b}} 、 \mathrm{x}_{\mathrm{b}-\mathrm{c}}$ 、同じく透視図上の隣接材との隙間 $\Delta \mathrm{x}_{\left(\mathrm{c}^{2-\mathrm{al})}\right.}$ は、それぞれ (3)、(4)、(5) 式となる。

$$
\begin{gathered}
x_{a-b}=\frac{(t+l) d \cos \theta}{(t+l) \sin \theta+d}-\frac{l d \cos \theta}{l \sin \theta+d} \\
x_{b-c}=\frac{l d \cos \theta}{l \sin \theta+d}-\frac{d(l \cos \theta-a \sin \theta)}{l \sin \theta+a \cos \theta+d} \\
\Delta x\left(c_{2}-a_{1}\right)=d\left\{\frac{l_{2} \cos \theta-a \sin \theta}{l_{2} \sin \theta+a \cos \theta+d}\right. \\
\left.-\frac{\left(a+l_{1}\right) \cos \theta}{\left(a+l_{1}\right) \sin \theta+d}\right\}
\end{gathered}
$$

図7〜9は、視距離 $\mathrm{d}=10 、 30 、 60 、$ 外壁面の直立 傾角 $\theta=30^{\circ} 、 60^{\circ}$ 、正方形断面の辺長 $t=0.5$ とし

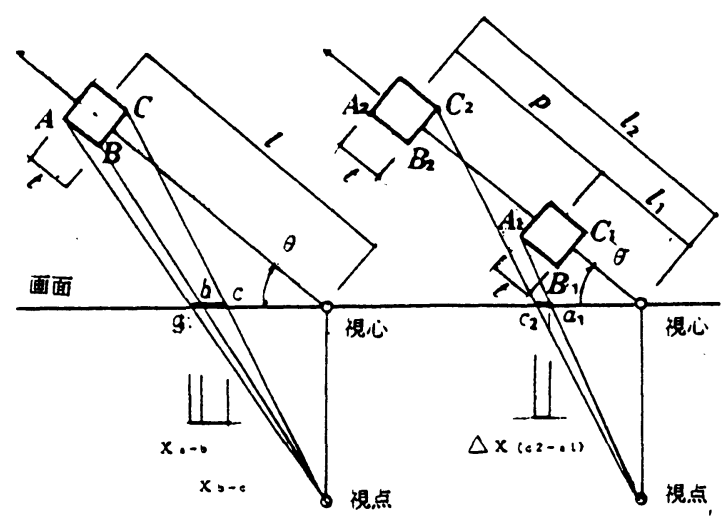

(1) 銛面材の回

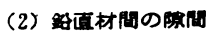

図6 正方形断面鈶直材の透視図を描く作図条件
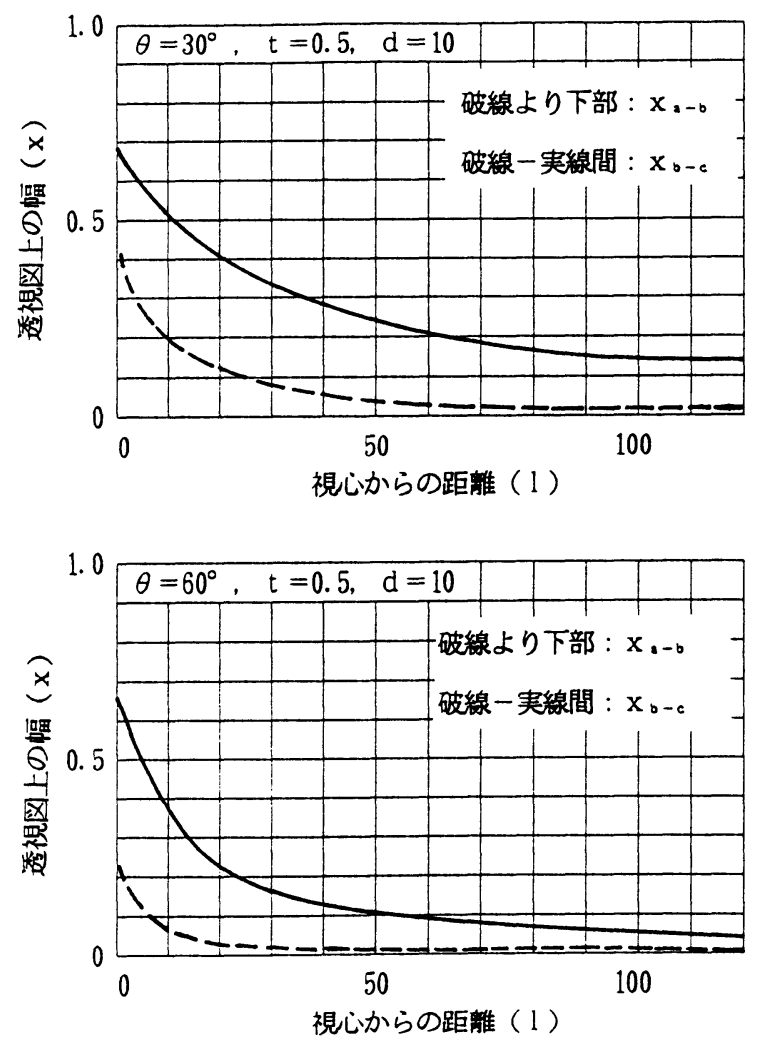

図7透視図上の正方形断面鈶直材の幅 $(d=10)$

たとき、透視図上、直立材の正面方向と側面方向の幅 がどのようになるかを図示したものである。破線より 下部が正面方向の幅、破線と実線の間が側面方向の幅 を表わしている。

隣接柱との間隔については、紙幅がないため、計算 結果の図示を割愛した。

\section{3 補足説明}

本報告では外壁面の直立傾角を $30^{\circ} 、 60^{\circ}$ に固定し たとき、鉛直材の透視図上の幅を、円形断面では $\mathrm{r}=$ 0.5、正方形断面では $t=0.5$ とおいており、寸法が 

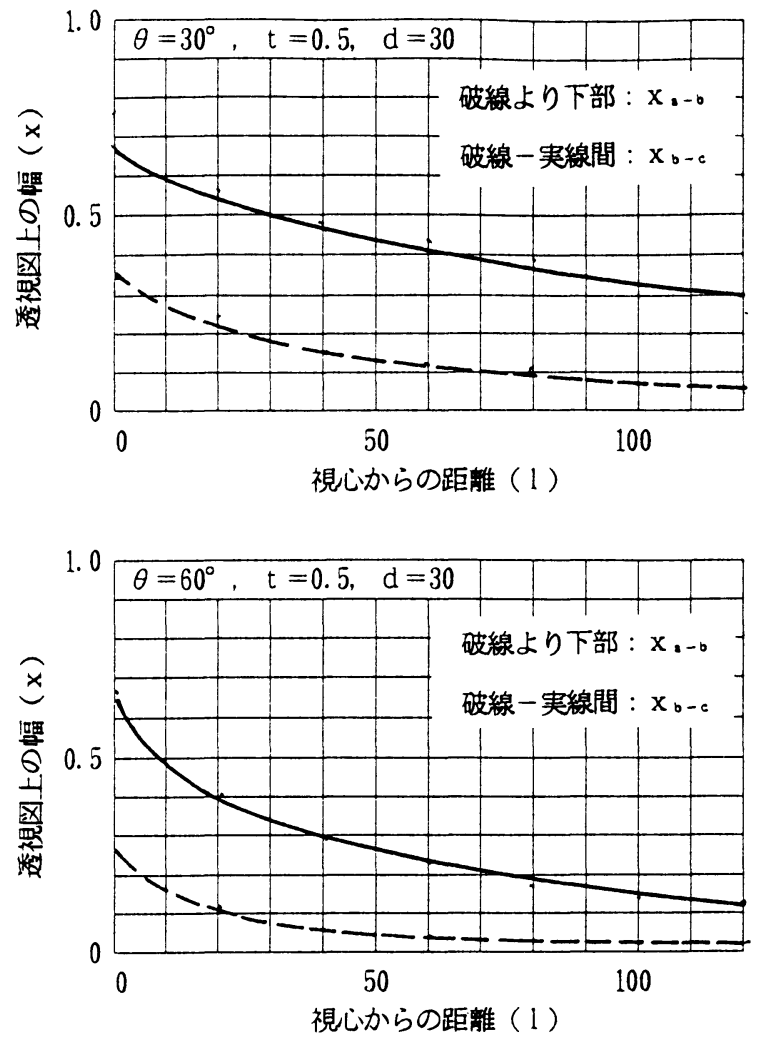

図 8 透視図上の正方形断面鈶直材の幅 $(\mathrm{d}=30)$
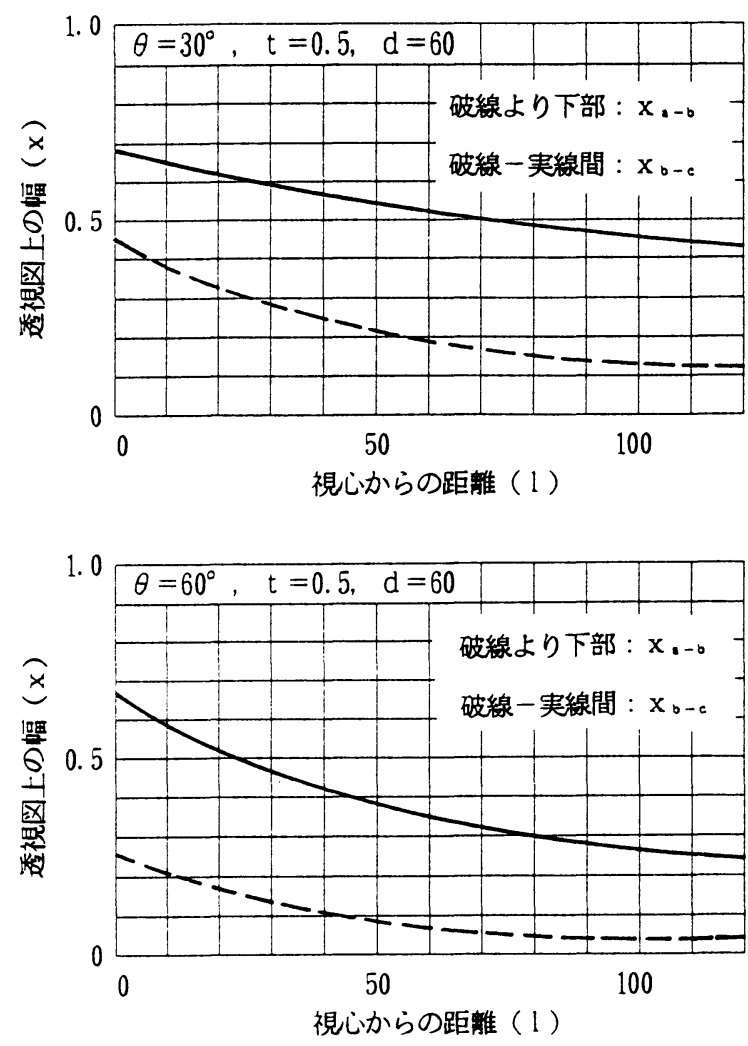

図 9 透視図上の正方形断面鈶直材の幅 $(d=60)$

異なるときは基準值に対する倍率を縦軸の読み取り值 に乗ずればよい。図 4、5、図 7〜9の数值はm、c m、 $\mathrm{mm}$ のいずれでもよい。例えば、m単位の原寸で描い た透視図上の鉛直材の幅はm単位で読むが、1/100 の平面図を用いて描いた場合は c m 単位となる。

4. 3 簡略表現の指標値について

最小径の製図用ペン $(0.1 \mathrm{~mm})$ で正方形断面鉛直材 の正面を 2 本線で表現しようとする場合、 $0.5 \mathrm{~mm}$ 以下 の空白部への着色不能とすれば、これに輪郭線の幅を 加えた $0.7 \mathrm{~mm}$ 未満は 1 本線で表わすことになる。

タイルやプレキャスト板、あるいは鉄笳コンクリー 卜造建物のひひ割れ誘発目地の幅は $0.5 \sim 2.0 \mathrm{~cm}$ 程度 である。図 7〜9を用い逶視図に描き込む大凡の目地 幅を求めることができる。当然のことながら、透視図 上 $0.1 \mathrm{~mm}$ 以下となる目地を製図ペンで描くと、実際よ りも目地を太く表現することとなり、遫視図の遠近感 やスケール感を損ねる結果となる。

\section{5.まとめ}

本論では、(1)集合住宅の販売広告などで通常目にす る CAD作品について省略のない均質な描写か建物の 遠近感とスケール感を損なうことを指摘し、(2優れた 建築パース作品を分析して省略遠近法の具体的技法を 把握し、(3)建物正面と側面の奥行き感やテクスチャア を表現する上で省略遠近法か特に問題となる鉛直材に 関する検討資料を若干提示した。

\section{【注記】}

1）新聞折込広告に掲载された集合住宅 3 例と不動産会社の広 報誌に载った户建て住宅のパース1例て、いずれも市販の C A Dを使って描いたものである。

2）作品集1)、2)から抜粋したパース尃門家による手描きの透 視図て、戸建て住宅、店舗各 1 例、集合住宅 2 例

3）日本人画家が描いたヨーロッパの古い街並み 2 例、芸大出 身の建筑家が描いた日本の近代商業建筑 1 例、アマチュア 画家が描いた小樽の古い家並み 1 例

4) 本論は辻美奈子の卒論》) を要約したものてある。

\section{【文献】}

1）成瀬嶺雄編：現代の建築パース、ドーム社 (1973)

2) グラフィック社編集部：建築パース集成、グラフィック社 (1981)

3）村上末吉編 : 15人のレンダラーによるパースの彩色テクニ ック (1993)

4）福永文昭 : 建築パース・即戦カテクニック、グラフィック 社 (1993)

5）宮後浩：実践パース、学芸出版社（1993）

6）島田恵子：透視図の原形態を適切に表現する視点位置、北 海道大学卒業論文 (1996)

7）浅川泰子、佐藤仁一朗、井野智：原形態を最も適切に表現 する透視投象、日本図学会年次大会 (北海道) 学術講演論 文集、21-26 (1998)

8）辻美奈子：透視図亡絵画における省略遠近法、北海道大学 卒業論文 (1999) 